\title{
THE IMPACT OF THE INTERNET ON TRADE IN EDUCATION
}

\author{
Christina TAY \\ Chinese Culture University, Taipei, Taiwan \\ Received 17 July 2014; accepted 08 February 2015
}

\begin{abstract}
The purpose of this study is to investigate how the Internet impacts trade in education. Divided into three time frames - 2000 to 2006, 2007 to 2012 and 2000 to 2012, data on 189 countries was used to compare the impact of different intensities of the Internet access on trade in education. This research uses the following methods to analyse data: pooled ordinary least squares regression, fixed-effects model and random effects model. Results suggest that the Internet facilitates trade in education, the impact of which is between $16.4 \%$ and $21 \%$ for every $0.01 \%$ increase in Internet access. Larger countries and countries that share a common language show a highly significant impact of the Internet on trade in education for all three time frames at $0.01 \%$. However, economic health of a country does not necessarily imply greater trade. This study finds mixed results for fixed (wired) broadband over the three time frames. The results explain between $63.2 \%$ and $74.9 \%$ of the impact of the Internet on trade in education. Finally, the results of this study strongly suggest that improving Internet access in a country will stimulate trade in education.
\end{abstract}

Keywords: internet, fixed broadband, trade, education, information and communications technology.

JEL Classification: F01, F10, F14, O30.

\section{Introduction}

Intuition tells us that information and communication technologies (ICT) have enabled the production of many services and service activities, and is no longer subjected to locational or information asymmetry. Improvements in technology, standardization, infrastructural growth and decreasing data transmission costs have all facilitated the sourcing of services and service activities to and from abroad. Rapid advances in ICT have also increased the tradability of many service activities and created new kinds of tradable services (OECD 2007). Trade in education is no exception to this globalizing trend.

The Internet has influenced the economy in every respect (Choi, Yi 2009). The impact of the Internet on our economy is too extensive to be summarized shortly (Choi 2010). In

Corresponding E-mail:

christina@sce.pccu.edu.tw 
terms of Gross Domestic Product (GDP per capita), trade in education has become one of the single largest services sector and employment for many economies. Trade in education also provides the bulk of employment and income in many countries and serves as a vital input for producing other goods and services (Tay 2014a). The education sector has been accounted for as one of the top and growing service exports sector for many traditional top competitors including the United States, United Kingdom, Australia, France and Germany, as well as new emerging Asian contenders such as Malaysia, Singapore, Taiwan and Japan. Trade in education is one of the major contributors of GDP for Australia, the United Kingdom, New Zealand, Canada as well as the United States (Tay 2014b).

Taking into account a total of 191 countries, trade in education increased $91.1 \%$ from 2000 to 2012 (UNESCO 2000-2012). As for many developed countries, trade in education has been one of the top service exports. For Australia, education and training was the largest service export, accounting for 28\% of services exports in 2012-13 (DFAT 2013; AIBS 2014). For the United Kingdom, education exports were worth $£ 14$.1billion in $2008 / 09$ (BIS 2011). By 2020, the United Kingdom estimates that its share in the global exports in education will be at $10 \%$ with compound annual growth of $9.1 \%$ (Bohm et al. 2004). For Canada, trade in education translates to almost $\$ 4.2$ billion in Gross Domestic Product (GDP, hereinafter) contribution, representing about 7\% of its GDP (Kunin et al. 2012).

A few strands of literature study the impact of the Internet on trade. One strand of literature examines the impact of communication costs on trade. For example, Limão and Venables (2001) focus on communication infrastructure while both Fink et al. (2005) and Tang (2006) focus more on communication costs. The second strand of literature focuses on how the Internet/ICT impacts economies at various levels: (a) at a country level - for example in a study by Wang (1999) which focuses on Taiwan; (b) at a regional level - for example in a study by Kenny (2003) which focuses on Less Developed Countries; and, (c) at an intra-regional level - for example in a study by Bankolea et al. (2015) which focuses on the intra-African region. The third strand of literature emphasizes on how the Internet impacts trade in services. Grossman and Helpman (1995) study the relationship between technology and trade. They examine not only how technology affects trade, but also how trade affects the evolution of technology. In their study, they are largely concerned with how the international trading environment affects the pace and direction of technological change. By adding structure to the Ricardian model, they are able to shed light on some commonly observed trade dynamics. Freund and Weinhold (2002) investigate the impact of the Internet on service trade using detailed data on "Other Private Services" from 31 countries and 14 industries from 1995 to 1999. A fourth strand of literature examines how trade stimulates Internet use. For example, Caselli and Coleman (2001) suggest that the "extent to which a country is integrated into the global economy can play a role in its access to ICT and argue that countries open to imports from high-income Organization for Economic Co-operation and Development (OECD) economies will benefit from knowledge spill-overs and, hence, are more likely to adopt new technologies. Clarke and Wallsten (2006) investigate if developing countries export more to developed, but not other developing countries, when Internet penetration is higher. 
One of the most dramatic changes in the revolution of ICTs took place in the mid-late 1990s and early 2000s. Such advancements in ICTs have brought basic telecommunications services within the reach of many. In 1995, the year of the birth of the Internet, less than $1 \%$ of the world population had Internet access. In 2014, over 2.9 million or $40.4 \%$ of the world population had Internet access, showing a fortyfold growth. Figure 1 shows the Internet penetration rate by region in 2014. Europe ranks first with the highest Internet penetration rate, followed by the Americas at 65.5\%, Commonwealth of Independent States at 55.9\%, Arab States at $40.6 \%$, Asia and Pacific at $32.4 \%$ and Africa at $19 \%$. The World's average for Internet penetration rate stood at $40.4 \%$ in 2014 (ITU 2014).

The Internet growth rate in the late 2000s was somewhat retarded in previously high penetration rate regions such as the Americas, Europe and Asia. On the other hand, the growth rates for low penetration regions such as Africa, Commonwealth of Independent States and the Arab States was at a high at 14\%, 95.3\% and 55.2\%, respectively in the late 2000s. Countries with the top five Internet penetration rates in the world in 2014 were Bermuda, Qatar, Bahrain, Iceland, Norway and Netherlands. Countries with the highest growth rates in 2014 compared to the previous year include Oman, Zimbabwe, Angola, Uganda and Zambia (Internet World Stats 2014).

Figure 2 shows the regional fixed (wired) broadband subscriptions (in millions) per 100 inhabitants in 2014. Just as in Internet penetration rates, Europe led with the highest fixed(wired) broadband subscriptions in 2014 at $27.7 \%$, followed by the Americas at $16.7 \%$,

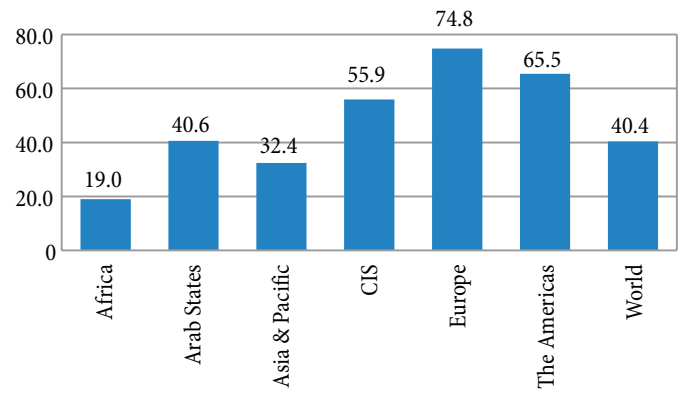

Fig. 1. Internet penetration rate (in millions) per 100 inhabitants (2014)

Source: Internet World Stats (2014).

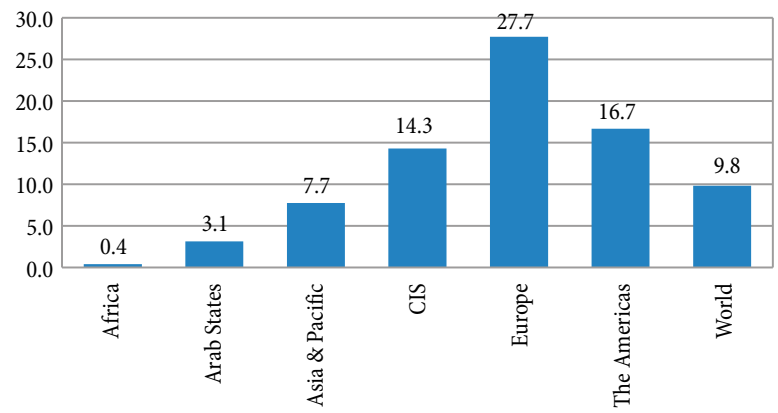

Fig. 2. Fixed (wired) broadband subscriptions (in millions) per 100 inhabitants (2014) Source: ITU (2014). 
the Commonwealth of Independent States at 14.3\%, Asia and Pacific at 7.7\%, Arab States at $3.1 \%$ and Africa at $0.4 \%$. The world's average subscriptions of fixed (wired) broadband in 2014 stood at $9.8 \%$. In order of highest to lowest, the growth rate of fixed (wired) broadband subscriptions from 2000 to 2014 for Africa was at $243 \%$, Commonwealth of Independent States at $179 \%$, Arab States at $165 \%$, Asia Pacific at $141 \%$, the Americas at $119 \%$, and finally, Europe at 118\% (ITU 2000-2014).

Analysis of the current trends of global ICT accessibility by region informs us that the growth of ICT usage has not only increased dramatically over the years, but its usage is still growing. However, in terms of the Internet and fixed (wired) broadband, variations in their accessibility are found over time. One preliminary implication of this is that there may be cross-region variations in ICT access and growth in ICT access due to different patterns of economic growth. The different stages of economic development including developed, transitional and developing economies over the long term make it harder to generalize the impact of ICT on countries, as a whole.

Although trade in education and Internet growth appears to have occurred contemporaneously, the two changes may not be necessarily linked and such timing could simply be coincidence. However, cross-country evidence suggests a relationship between the Internet and globalization. Countries that trade more tend to have higher Internet penetration rates. New communication possibilities such as the Internet are creating rapidly the conditions that could allow such trade to flourish in the future (Larsen et al. 2002). Thus, the impact of the Internet access raises an important issue in trade in education. A major research initiative is required to improve our understanding in this area and as "to what extent" the Internet boosts trade in education.

An examination of existing literature finds that studies that examine the impact of the Internet on trade in education have been largely ignored despite the growing importance of both the Internet/ICT and trade in education. A major research initiative is required to improve our understanding in this area as to what extent the Internet boosts trade in education. This study expands on existing studies in several ways. First, this paper uses extensive trade data from 189 countries over the period 2000 to 2012 to study the Internet effect. This irons out the variations across countries and over time that may be due to stages of economic development. In addition, most existing studies use data of much shorter time spans or of time spans that do not include latest data. Second, three methodologies are used: the Ordinary Least Squares Regression, fixed time effects, and the random effects model. Third, this study expands upon existing studies on the impact of the Internet on trade in services by Freund and Weinhold $(2002,2004)$ in two ways. First, while Freund and Weinhold (2004) use the total number of Web hosts attributed to each country as the measure of the Internet, this study uses Internet usage intensity. Internet usage intensity is the number of the Internet users per 100 people who can access the worldwide network. We argue that capturing Internet usage intensity will be able to measure trade more directly than the total number of Web hosts. Second, this study bridges the gaps in existing studies by examining the impact of the Internet on trade in education, a research area that is particularly scant. For example, while the study by Freund and Weinhold (2002) is confined to US business and professional service imports, this study builds upon the latter study by 


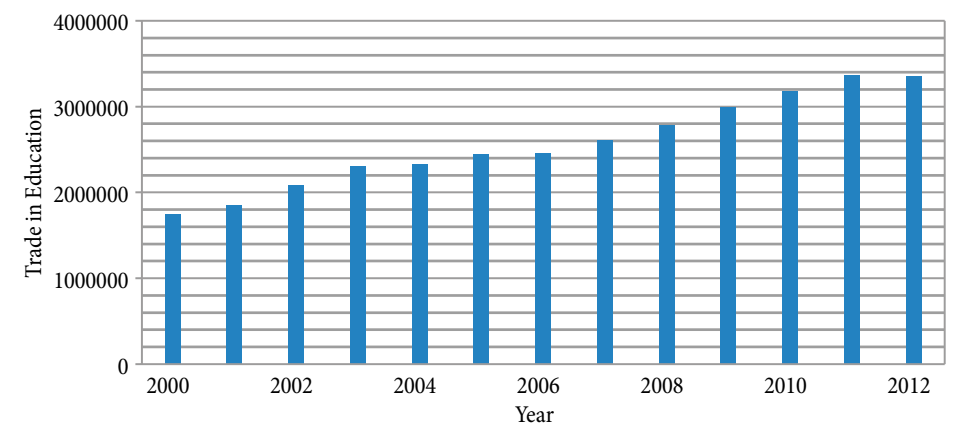

Fig. 3. Trade in education, 2000 to 2012 (number of internationally mobile students) Source: OECD (2000-2012).

expanding the model to include world data on 189 countries, instead of just 31 countries. It also includes a greater time span of thirteen years from 2000 to 2012, instead of just four years from 1995 to 1999. Finally, this paper also compares the three time frames. Two shorter time frames are first examined. The first time frame extends from 2000 to 2006, a period when Internet accessibility was higher in developed countries than less developed countries. The second time frame extends from 2007 to 2012, a period when Internet accessibility gradually increased in lesser developed countries. A longer, aggregated time period extending from 2000 to 2012 is also investigated. These different time frames allow us to compare the different intensities of Internet access with the assumption that Internet accessibility increases over time as shown in Figures 1, 2 and 3 as aforementioned. Since this study data includes a large range of countries from different stages of economic development: developed, transitional, and developing economies; it is posited that the conclusions provided may be easier to generalize and justifications not blurred as a result.

The rest of this paper is arranged as follows: Section 1 reviews related literature. Section 2 discusses the model, data and measurement issues, Section 3 presents the empirical results, and the last Section concludes.

\section{Literature review}

Trade in services is information dependent (Lanvin 1989). This hypothesis holds true also for trade in education given that education is a highly intangible service. Thus, the importance of ICT/Internet cannot be highlighted more in the area of trade in education. This paper draws from several streams of literature. The first strand of literature examines the impact of communication costs on trade. In this context, we examine the theory and evidence concerning the impact of differing communication costs on trade in goods or services. This first strand of literature emphasize on communication costs and their impact on trade. Limão and Venables (2001) focus on communication infrastructure while studies by Fink et al. (2005) and Tang (2006) focus more on communication costs itself. Limão and Venables (2001) constructed an index of infrastructure density including availability of telecommunications and find that it is a significant determinant of bilateral trade. They also 
find infrastructure to be an important determinant of transport costs, especially for landlocked countries. Analysis of bilateral trade data confirms the importance of infrastructure and gives an estimate of the elasticity of trade flows with respect to the trade cost factor of around -3 . A deterioration of infrastructure from the median to the 75th percentile raises transport costs by 12 percentage points and reduces trade volumes by 28 percent. Analysis of African trade flows indicates that their relatively low level is largely due to poor infrastructure. Fink et al. (2005) tests the relationship between communication costs as an important determinant of trade costs in a model of bilateral trade. Communication-related effect of trade costs is the per-minute bilateral calling price charged in the importing and exporting countries. They find that international variations in communication costs indeed have a significant influence on trade patterns. Furthermore, estimates using disaggregated data reveal that communication costs are more important for trade in differentiated products than for trade in homogenous products. Tang (2006) investigates how the decline of communication costs affects the pattern of trade in differentiated goods and finds that the development of information technology (IT) significantly increases US imports of differentiated goods after the 1970s. In addition, modern communication technology assisted small economies from exporting homogeneous goods to exporting more and more differentiated goods.

The second strand of literature focuses on how the Internet/ICT impacts economies at various levels: (a) at a country level - for example in a study by Wang (1999) which focuses on Taiwan; (b) at a regional level - for example in a study by Kenny (2003) which focuses on Less Developed Countries; and, (c) at an intra-regional level - for example in a study by Bankolea et al. (2015) which focus on the intra-African region. Wang (1999) examines the impact of ICT/Internet at the country-level, taking Taiwan as an example based on longitudinal data over 16 years. It highlights the joint impact of national IT capabilities and national IT investment on economic growth, and the findings imply that the payoff effect of IT investment on economic growth can be achieved only through a robust national information infrastructure that supports IT adoption and application. Kenny (2003) brings about a theoretical perspective that is supported by empirical evidence that the impact of technology on developing countries has potentially negative implications. This theoretical perspective is supported by the empirical evidence on the limited impact of past "information revolutions" on less-developed countries (LDCs) and the present impact of the Internet on advanced economies. Furthermore, LDCs appear ill-prepared to benefit from the opportunities that the Internet does present - they lack the physical and human capital, along with the institutions required, to exploit the e-economy. Finally, even optimistic forecasts of the Internet's global economic impact are small in scale compared with the challenge of development. This has significant implications for development policy. Bankolea et al. (2015) investigate the impact of ICT/Internet at a regional level, considering intra-African trade. This study investigates how information and communications technology (ICT) infrastructure impacts on intra-African trade, taking into account other relevant factors that also influence trade such as Institutional Quality and Educational Attainment. The empirical analysis shows that the Telecommunications Infrastructure has a major impact on intra-African trade. Interacting factors such as Institutional Quality and Educational Attainment also play a role in influencing intra-African trade. 
The third strand of literature emphasizes on how the Internet impacts trade in services. Grossman and Helpman (1995) research on the relationship between technology and trade. They treat the state of technology as exogenous and ask how changes in technology affect the trade pattern and welfare, emphasizing the parallels between the models with learning-by-doing and those with explicit research and development and highlight the role that geographic extent of knowledge spill-overs plays in mediating the relationship between trade and technological progress. Freund and Weinhold (2002) investigate the impact of the Internet on service trade using detailed data on "Other Private Services" from 31 countries and 14 industries from 1995 to 1999 . They find effects of the Internet on US business and professional service imports more than doubles on overall US service imports. An increase in a country's Internet access will facilitate an increase in its service trade with other countries. Freund and Weinhold (2004) extend their study from 2002 to investigate if Internet stimulates trade measured by the number of web hosts in a country and find that the Internet stimulates trade. Results suggest that a 10 percentage point increase in the growth of web hosts in a country leads to about a 0.2 percentage point increase in export growth. For the average country in our sample, the Internet contributed to about a 1 percentage point increase in annual export growth from 1997 to 1999. There is also evidence of proximity-biased trade growth. Clarke and Wallsten (2006) distinguish between trade volumes between developing and developed countries with Internet penetration, and find that developing countries export more to developed, but not other developing countries, when Internet penetration is higher. Although this could be because Internet penetration stimulates exports, it could also be because trade openness encourages Internet use. To test the direction of causation, Internet use is determined to endogenous using countries' regulation of data services as an instrument. The results suggest that access to the Internet does improve export performance in developing countries, although not in developed countries. In other words, improving Internet access in a developing country will stimulate exports from that country to relatively richer countries. A greater panel data consisting 207 countries of ten years is used by Choi and Yi (2009) to investigate the effect of the Internet on service trade. This study differs from the studies by Freund and Weinhold $(2002,2004)$ in that it uses a vast number of countries instead of just one country (the US) as a base. Choi and Yi (2009) find evidence that the Internet plays a positive and significant role in economic growth after investment ratio, government consumption ratio, and inflation are used as control variables in the growth equation. The increase in Internet users per hundred people proves to increase total service trade, as well as service export and service import. A 10\% increase in Internet users per hundred people turned out to increase service trade from $0.23 \%$ to $0.42 \%$. The measured effect of the Internet on services trade, while significant is actually small because this is aggregate services trade. A doubling of Internet usage in a country turned out to lead to a 2 to $4 \%$ increase in services trade. An increase in a country's Internet access will facilitate an increase in its service trade with other countries. Choi (2010) uses a much larger sample of countries consisting 151 countries from 1990 to 2006 to investigate the effect of the Internet on service trade. Using a pooled ordinary least squares regression, a fixed-effects model, and a panel GMM, the increase in Internet users per hundred people proved to increase total service trade, as well as service export 
and service import. A $10 \%$ increase in Internet users per hundred people turned out to increase service trade from $0.23 \%$ to $0.42 \%$. The measured effect of the Internet on services trade, while significant is actually small because this is aggregate services trade. Vemuri and Siddiqi (2009) use a greater panel of data to test the proposition that information and communication technology (ICT) and the Internet have enhanced trade. They argue that their study is the first to use a sufficiently lengthy series to make valid comparisons of trade before and after the commercialization of the Internet. Their study uses a balanced panel data for 64 countries (representing many phases of economic development) for the years 1985 to 2005, and an instrumental variable approach of Hausman and Taylor, as well as other panel data methods to provide an adequate basis for their conclusions. The results of their study are unequivocal and robust. There is a positive and significant effect of ICT infrastructure and the availability of the Internet for commercial transactions on the volume of trade.

The fourth strand of literature examines how trade stimulates Internet use. For example, Caselli and Coleman (2001) suggest that the "extent to which a country is integrated into the global economy can play a role in its access to ICT. They argue that countries open to imports from high-income Organisation for Economic Co-operation and Development (OECD) economies will benefit from knowledge spill-overs and, hence, are more likely to adopt new technologies. They use time-series data from the US over the period 19631992. Empirical studies of Internet penetration find that Internet use is correlated to the level of development of a country. For example, Clarke and Wallsten (2006) investigate if developing countries export more to developed, but not other developing countries when Internet penetration is higher. Although this could be because Internet penetration stimulates exports, it could also be because trade openness encourages Internet use. To test the direction of causation, they allow Internet use to be determined endogenously using countries' regulation of data services as an instrument. The results suggest that access to the Internet does improve export performance in developing countries, although not in developed countries. In other words, improving Internet access in a developing country will stimulate exports from that country to rich countries. In another study by Baliamoune (2002), data from developing countries is used to examine the links between ICT diffusion and per capita income, trade and financial indicators, education, and freedom indicators. Internet hosts, Internet users, personal computers and mobile phones represent indicators of ICT. The Gompertz model of technology diffusion is used to study ICT dissemination. The results show that income and government trade policies influence ICT diffusion. However, freedom indices may or may not affect ICT diffusion. Moreover, only personal computers and Internet hosts seem to have a positive association with income. Contrary to expectations, ICT diffusion is not associated with education.

The fifth strand of literature examines the role of trade on international technology transfer. For example, Saggi (2002) research if technologies introduced by multinational firms diffuse to local firms and examine the kinds of policies that prove successful in encouraging technology absorption from abroad, paying particular attention to the role of foreign direct investment. The literature argues that trade necessarily encourages growth only if knowledge spill-overs are international in scope. Damijan et al. (2003) examines the different 
channels of global technology transfer to transition countries and study the impact of direct technology transfer through foreign direct investment, intra-industry knowledge spill-overs from foreign direct investment, firm's own research and development accumulation, and research and development spill-overs through trade for total factor productivity growth of local firms. Using firm-level data for eight transition countries for the period 1994-1998, they find that technology is being primarily transferred to local firms through direct foreign linkages. Results also suggest that foreign direct investment do not generate positive intra-industry spill-overs for domestic firms.

Upon review of existing literature, we find five diverging strands of literature, none of which converges to investigate on the impact of the Internet/ICT on trade in education. The first strand of literature relates to communication costs and its impact on trade, in general. The second strand relates to the impact of the Internet on trade in services. The third strand relates to the Internet/ICT on the economy as a whole. The fourth strand relates to how trade stimulates Internet use. Finally, the fifth strand relates to the role of trade on technology transfer. In this paper, I attempt to bridge the gaps in existing streams of literature by investigating the impact of the Internet/ICT on trade in education of national economies.

\section{Data, measurements and model specification}

\subsection{Data sources}

The data for this study is obtained for the period 2000 to 2012 from several archival sources. Data on information and communications technology is obtained from International Telecommunication Union (ITU, hereinafter). The ITU is one of the United Nation's groups with the most reliable source of data for the information and communications technology sector. The ITU develops a composite index to monitor and compare development of ICT across countries called the ICT Development Index (IDI), reflecting the level of ICT readiness, ICT intensity and ICT skills in a respective country. Indicators of ICT readiness include fixed-telephone line penetration, mobile-cellular telephone subscriptions, international Internet bandwidth (bit/s) per Internet user, the percentage of households with a computer and percentage of households with Internet access. ICT intensity indicators include percentage of individuals using the Internet and fixed (wired)-broadband subscribers per 100 inhabitants. For purposes of this study, data provided by ITU from 2000 to 2012 are used to measure the indices for the Internet (Internet World Stats 2000-2012).

The World Bank group compiles statistical profiles for all countries in the world in a well-organized database. Data from the World Bank (2000-2012) are used to measure the gross domestic product (GDP per capita, in US dollars), and world population. Data on trade in educational services is obtained from the database on Trade in Services and from the OECD Indicators for Education Systems (INES) dataset on foreign students in tertiary education. Since international flows of students in higher education constitute by far the largest share of the global market for trade in education, it is used as a proxy for trade in education. A total of 189 countries exporting higher education are used in our estimations. Appendix A lists all of the countries included in the study. 


\subsection{Measurement for trade in education}

Lipsey (2009) states that more and more of measurements of trade place a great deal of weight on the definition of residence, because the identification of residence can change what is, on the face of it, a domestic transaction into an international transaction. Larsen et al. (2002) define foreign students in tertiary education as in the OECD/Eurostat classification. Under this classification, "trade in educational services" data is accounted by the host country when incoming foreign students come from a particular country. Foreign students are usually identified on the basis of citizenship, or in some cases, by an alternative criterion (e.g. nationality, place of birth or former domicile). This data also refers to Mode 2 in the WTO classification as Consumption abroad, which refers to a situation where a service moves to another country to obtain a service in question (WTO 2010). International flows of students in higher education constitute by far the largest share of the global market for education services. Bourke (2000) states that foreign students are the most visible aspect of trade in services and take foreign students or internationally mobile students of which he/she is not a residence of as the most visible form of trade in education.

In this study, our measurement for trade in education places weight on the definition of residence. We combine the measurement concepts of service and trade as in Larsen et al. (2002) and Lipsey (2009). Our measurement for trade in education is one that accounts for an incoming foreign student from a home country who consumes or invests in education in a host country of which he/she is not a citizen of.

\subsection{Econometric model}

Gravity models have been used extensively in the past by Tinbergen (1962), Poyhonen (1963) and Aitken (1973) to analyze patterns and performances of international trade. It has been long recognized for its consistent empirical success in explaining many different types of flows, such as migration, commuting, tourism, and commodity shipping (Bergstrand 1985). The gravity model has gone a long way and acquired a strong reputation of good fitting and dominates literature on trade. The basic notion of the gravity model applies Newton's universal law of gravitation in physics, which states that the gravitational attraction between two objects is proportional to their masses and is inversely related to the square of their distance. The basic theoretical model of trade between two countries takes the following form:

$$
X_{i j}=C . \frac{G i^{\star} G j}{D i j},
$$

where, $X_{i j}$ is the bilateral trade between countries. $G_{i}$ and $G_{j}$ are the gross domestic product of countries, $i$ and $j$, respectively. $D_{i j}$ is the distance between the trading countries. And, $\mathrm{C}$ is a constant.

A commonly used revised manifestation of the gravity model is as follows:

$$
X_{i j}=G_{i} G_{j} D_{i j} e,
$$

where, $X_{i j}$ is the bilateral trade flows of country $i$ into country $j . G_{i}$ is the GDP of the 
importing country, whilst $G_{j}$ is the GDP of the exporting country. $D_{i j}$ is the distance between country $i$ and $j$. Finally, e is a log-normally distributed error term.

Mátyás (1997) argues that the correct gravity specification is a three-way model. One dimension is time that reflects the common business cycle or globalization process over the whole sample of countries. The other two dimensions of group variables are time invariant export and import country effects. Following Mátyás (1997), Equation (1.3) is modeled as below as a correct econometric representation of the gravity model, taking a triple-indexed model:

$$
\ln X_{i j t}=e_{i}+\lambda_{j}+\Psi_{t}+\beta 1 \ln G_{i t}+\beta 2 \ln G_{j t}+C L_{i j} \ldots+e_{i j t},
$$

where, $X_{i j t}$ is the volume of trade between country $i$ and $j$, at time, $t$. $G_{i t}$ is the GDP in country $i$ at time, $t$. $G_{j t}$ is the GDP in country $j$, at time, $t . D_{i j}$ is the distance between the countries $i$ and $j . i=1, \ldots, N, J=1 \ldots, i-1, i+1, \ldots, N+1$, where the $N+1$-th element here is the rest of the world. $v_{\mathrm{i}}$ is the local country effect, $i=1, \ldots, N ; \lambda_{j}$ is the target country effect, $j=1, \ldots, N+1 ; \Psi_{\mathrm{t}}$ is the time-specific effects, $t=1, \ldots, T$; and $e_{i j t}$ is a white noise disturbance term.

We then take into account the local, target and time effects and rewrite the model in vector form:

$$
v=d_{n} \Phi+d_{i} \delta+d_{t} \theta M \zeta+e,
$$

where, $\mathrm{v}$ is the $\left(n^{*} n^{*} t\right)^{*} 1$ vector of observations of the dependent variable $X$ :

$$
v=\left[v_{171}, v_{172}, \ldots, v_{181}, v_{18 \mathrm{t}}, v_{n 11}, \ldots, v_{n 1 t}, \ldots, v_{n(n-1) 1}, \ldots, v_{n(n-1)}, v_{n(n+1) 1}, \ldots, v_{n(n+1) t}\right] \text {. }
$$

$M$ is the matrix of observations of the explanatory variables in equation (3) organized in a similar way as $X_{i j t} . d_{n}, d_{i}$ and $d_{t}$ are dummy variable matrices $\left(d_{n}=\operatorname{sn}^{\star} w_{n t}\right),\left(d_{i}=s_{n}{ }^{2 \star} w_{i t}\right)$, $\left(d_{t}=s_{n}{ }^{3 *} w_{t}\right) . s$ is the vector of ones with its size in the index, and $\mathrm{w}$ is the identity matrix. $\Phi$ is an $\left(n^{\star} 1\right), \delta$ is a $\left(t^{\star} 1\right), \theta$ is an $\left((n+1)^{\star} 1\right), \zeta$ is a $\left(k^{\star} 1\right)$ parameter vector with $\mathrm{k}$ the number of explanatory variables, and $\mathrm{e}$ is the vector of disturbance terms. The structure of the $d_{i}$ matrix is as follows:

$$
d j=\left(\begin{array}{c}
\vee \\
l \\
\vdots \\
l^{(1)}
\end{array}\right),
$$

where: $l^{(1)}=(0 \ln )$ and $\stackrel{\vee}{l}^{(1)}=l^{(1) \star} l_{t} ; l^{(n)}=\left(\begin{array}{lll}l_{n-1} & 0 & \\ & 1\end{array}\right)$ and $l^{(n)}=l^{(n) \star} l_{t}$.

In Equation (5), a dummy variable common language $\left(C L_{i j}\right)$ is inserted. If a partnering country shares a common language, either English or Spanish with the US, then a value of 1 is assigned, which otherwise would assume a value of 0 . It is hypothesized that existence of a common language encourages trade to the country if pairing countries share cultural similarities:

$$
\ln X_{i j t}=e_{i}+\lambda_{j}+\Psi_{t}+\beta 1 \ln G_{i t}+\beta 2 \ln G_{j t}+\beta 3 C L_{i j} \ldots+e_{i j t}
$$


Over the years, the gravity model has been augmented with additional variables to explain the remaining variability in trade. In this paper, we variables that reduce the fixed costs that consumers (international students) incur with sufficient Internet penetration are added. The intuition is that the Internet helps consumers acquire information about foreign institutions in other countries with web-based markets and networks share information about particular markets. The Internet effectively lowers the cost incurred by consumers. It is also posited that the advent of the Internet is likely to influence trade patterns. First, access to the Internet should increase trades because countries have more information about foreign markets and costs of accessing these markets are reduced. Second, the Internet should lead to higher overall trade.

Two variables which reflect the Internet penetration are used: (1) fixed (wired) broadband subscribers per 100 inhabitants $\left(F B_{j t}\right)$, and (2) Internet users per 100 inhabitants $\left(I N T_{j t}\right) . F B_{j t}$ refers to the number of broadband subscribers with a digital subscriber line, cable modem, or other high-speed technology. $I N T_{j t}$ refers to the percentage of population in a country who used the Internet (from any location) in the last 12 months. The Internet can be used via a computer, mobile phone, personal digital assistant, games machine and digital TV. Our Internet data comes from Internet Stats.

To test the impact of the Internet on trade in education (imports of other countries from the US), an augmented gravity equation is estimated. Here, the dependent variable is transformed to a unilateral trade in education $\left(\ln Y_{i j t}\right) \cdot \ln Y_{i j t}$ has three variations: $(1)$ the sum of trade in education, where $t=2000 \ldots 2006$; (2) the sum of trade in education, where $t=2007 \ldots 2012$; and (3) the sum of trade in education, where $t=2000 \ldots 2012$. The total number of outbound internationally mobile tertiary students studying abroad is used as a proxy for trade in education.

The augmented gravity model can now be estimated as below:

$$
Y_{i j t}=e_{i}+\lambda_{j}+\Psi_{t}+\left(G_{j}\right)^{\theta}+\left(P_{j}\right)^{\delta}+\left(F B_{j}\right)^{\mathfrak{B}}+\left(I N T_{j}\right)^{\mathrm{p}}+\left(C L_{i j}\right)^{\lambda}+e_{i j t} \text {, }
$$

where, $Y_{i j t}$ is the volume of trade between countries $i$ and $j$, at time, $t$. $G_{j t}$ is the Gross Domestic Product (in current US\$) in country $j$, at time, $t . P_{j t}$ is population in country, $j$, at time $t . \mathrm{v}_{\mathrm{i}}$ is the local country effect, where $i=1, \ldots, N . \lambda_{\mathrm{j}}$ is the target country effect, where $\mathrm{j}=1, \ldots, N+1 . \Psi_{t}$ is the time-specific effects, where $t=1, \ldots, T$. $e_{i j t}$ is a white noise disturbance term. Both $G_{j t}$ and $P_{j t}$ are included as independent variables to control for income effects and country size. Moreover, they may also proxy for a country's stage of technological development. The greater the level of developmental growth in a country, the more likely it is to have a greater percentage of Internet penetration. In more recent years, the growth of technological development is expected to be greater in lesser developed countries than developed countries, given that developed countries have greater access from the time of the birth of the Internet.

This article investigates the effect of the Internet on trade in education. If the Internet can provide new communication technologies leading to new or improved trading stimuli, then the Internet can potentially affect trade in education. To investigate this relationship, the following panel data model is utilized. This will be estimated by Ordinary Least Squares (OLS, hereinafter) where, $Y_{i j t}$ is the trade in education between the US, $i$, and 189 partnering countries, $j$ : 


$$
\ln Y_{i j t}=e_{i}+\lambda_{j}+\Psi_{t}+\theta \ln G_{j t}+\delta \ln P_{j t}+e \ln F B_{j t}+p \ln I N T_{j t}+\lambda C L_{i j}+e_{i j t},
$$

where, all the variables, except the dummy variables are real figures and expressed in logs, and the error term can be written as:

$$
e_{i j}=e_{i j}+r_{i j t} \text {, }
$$

where, $e_{i j}$ is the fixed or random unobserved bilateral effect, and $r_{i j t}$ is the remaining error. In this study, the panel approach is used since it has a few advantages. First, it is able to disentangle the time invariant country-specific effects. Second, panel approach can capture the relevant relationships among variables over time. Third, the panel approach can monitor unobservable trading-partner-pairs' individual effects. If individual effects are correlated with the regressors, OLS estimates omitting individual effects will be biased (Baldwin 1994; Mátyás 1997, 1998). Therefore, in this study the panel data methodology for our empirical gravity model of trade is used.

For panel econometric projection of trade, researchers have concentrated on the random effects model (REM), which requires that $e_{i j t ~}\left(0, \theta^{2}{ }_{e}\right), r_{i j t} \sim\left(0, \theta^{2}{ }_{v}\right)$, and the $e_{i j}$ are independent of the $v_{i j t}$. Moreover, the explanatory variables have to be independent of the $e_{i j}$ and $r_{i j t}$ for all cross-sections $(i j)$ and time periods $(t)$. The fixed effects model is always consistent in the absence of endogeneity or errors in the variables whereas the random effects model is only consistent if the above-mentioned orthogonality conditions are fulfilled. One may question the relevance of this regression in order to understand the barriers (and their costs) to trade in education.

Fixed effects regression methods are used to analyze longitudinal data with repeated measures on both independent and dependent variables. They have the attractive feature of controlling for all stable characteristics of the individuals, whether measured or not. Therefore, if a regression is a good fit using the fixed effects model, then trade in education between one country and another would not have any additional determinants other than those reflected in the regression equation. In this case, there would not be many non-quantifiable barriers to trade in education which might facilitate or hinder trade in education in the regression equation. And, if the random effects model applies, countryspecific effects do not matter.

\section{Empirical results}

\subsection{Ordinary least squares estimation}

A number of estimation techniques are applied to the model. We begin by estimating the gravity equation using conventional Ordinary Least Squares (OLS). Initially, the observations are pooled over three time frames in the dataset and the model is estimated with OLS of which results are presented in Table 1.

The augmented gravity model works well in a number of different dimensions. The model fits the data well, explaining $65.8 \%$ of the variation in trade flows for 2000-2006, $74.9 \%$ of the variation in trade flows for $2000-2006,71.9 \%$ of the variation in trade flows for 2000-2012. The results of our study show that the impact of Internet on trade in 
education grows over time as global ICT accessibility increases over the years, which is in line with global trends presented in the introduction section of this paper.

Results show that for 2000-2006, larger and richer countries trade more with highly significant result at $0.01 \%$. Countries which share a common language and have Internet access also trade more, showing highly significant results at $0.01 \%$. One exception is our results for fixed (wired) broadband which showed no significance at all for 2000-2006.

2006 to 2012 is a period of time of which is assumed that Internet access grows with time. We would expect our results for this time frame to differ for 2000-2006. Between 2007 and 2012, we find that richer countries do not necessarily trade more. However, larger countries trade more. Countries which share a common language also trade more in all three time frames. As for fixed (wired) broadband access between 2000 and 2006, results show an insignificant impact on trade in education. On the contrary, for every $0.01 \%$ increase in fixed (wired) broadband access, an increase of $7.7 \%$ of trade in education between 2006 and 2012 is found.

Table 1. Pooled panel OLS gravity estimates

\begin{tabular}{|c|c|c|c|}
\hline Time Frames & $2000-2006$ & $2007-2012$ & $2000-2012$ \\
\hline Models & (a) & (b) & (c) \\
\hline Dependent variables & \multicolumn{3}{|c|}{ Pooled Ordinary Least Squares } \\
\hline (c) $\log (G)$ & $\begin{array}{c}0.187 \\
(0.000)^{\star * * *}\end{array}$ & $\begin{array}{c}0.041 \\
(0.128)\end{array}$ & $\begin{array}{c}0.144 \\
(0.000)^{* * * *}\end{array}$ \\
\hline (d) $\log (P)$ & $\begin{array}{c}0.533 \\
(0.000)^{\star * * *}\end{array}$ & $\begin{array}{c}0.448 \\
(0.000)^{\star * * *}\end{array}$ & $\begin{array}{c}0.548 \\
(0.000)^{\star * * *}\end{array}$ \\
\hline (a) $\log (F B)$ & $\begin{array}{l}-0.003 \\
(0.659)\end{array}$ & $\begin{array}{c}0.077 \\
(0.000)^{\star \star \star \star}\end{array}$ & $\begin{array}{l}-0.005 \\
(0.557)\end{array}$ \\
\hline (b) $\log (I N T)$ & $\begin{array}{c}0.164 \\
(0.000)^{\star * * *}\end{array}$ & $\begin{array}{c}0.180 \\
(0.000)^{\star * * *}\end{array}$ & $\begin{array}{c}0.210 \\
(0.000)^{* * * *}\end{array}$ \\
\hline (e) CL & $\begin{array}{c}-0.259 \\
(0.000)^{\star * * *}\end{array}$ & $\begin{array}{c}-0.281 \\
(0.000)^{\star * * *}\end{array}$ & $\begin{array}{c}-0.271 \\
(0.000)^{\star * * *}\end{array}$ \\
\hline Constant & $\begin{array}{c}-1.350 \\
(0.000)^{\star * \star *}\end{array}$ & $\begin{array}{c}0.249 \\
(0.482)\end{array}$ & $\begin{array}{c}-1.328 \\
(0.000)^{* \star * *}\end{array}$ \\
\hline $\mathrm{R}^{2}$ & 0.658 & 0.749 & 0.719 \\
\hline No. of countries & 189 & 189 & 189 \\
\hline No. of observations & 1134 & 956 & 1824 \\
\hline Durbin Watson & 2.038 & 2.076 & 2.087 \\
\hline F-test & 433.420 & 567.315 & 929.725 \\
\hline VIF values & $\begin{array}{l}2.682 \\
1.385 \\
1.769 \\
3.003 \\
1.018\end{array}$ & $\begin{array}{l}3.797 \\
4.750 \\
8.680 \\
6.828 \\
1.045\end{array}$ & $\begin{array}{l}3.132 \\
2.212 \\
4.535 \\
5.744 \\
1.027\end{array}$ \\
\hline
\end{tabular}

Notes: Annual data for 189 countries; p-values are in parentheses; ${ }^{*}$ significant at $10 \%$, ${ }^{*}$ significant at $5 \%,{ }^{* * *}$ significant at $1 \%,{ }^{* * *}$ significant at $0.01 \%$; (a) $F B=$ fixed(wired) broadband subscribers per 100 inhabitants; (b) $I N T=$ Internet users per 10,000 inhabitants; (c) $G=G D P$ per capita; (d) $P=$ population of a country; (e) $C L=$ common language; VIF values are reported for each of the explanatory variables (a) (e). 
As for the aggregate period between 2000 and 2012, fixed (wired) broadband access shows an insignificant impact on trade in education. Overall, I find mixed results and variations for fixed (wired) broadband over the three time frames. These results are in line with global trends presented in the introduction section, where the implication was that there may be cross-country variations in access of fixed (wired) broadband due to different patterns of economic growth as well as different stages of economic development making it harder to generalize its impact on trade. On the contrary to fixed (wired) broadband, results for the Internet are highly significant for all three time frames. For every $0.01 \%$ increase in Internet access, trade in education increases by $16.4 \%$ between 2000 and 2006 by $18 \%$ between 2007 and 2012, and by $21 \%$ between 2000 and 2012. Results also show that having a common language between countries plays a highly significant factor for trade in education for all three time frames at $0.01 \%$.

Results show greater significance of the impact of the Internet than existing studies by Choi (2010), and Freund and Weinhold (2002). Existing studies by Choi (2010) find that for every $1 \%$ increase in Internet users per hundred people, service exports increase by $4.3 \%$. The results of the study by Freund and Weinhold (2002) find that for every $10 \%$ increase in Internet users per hundred people, exports grow by $0.2 \%$. The results of our study not only show similar trends, but one of much greater significance on trade in comparison.

So far, we have assumed that the Internet causes trade. However, it is also possible that trade can impact the Internet. Therefore, a check to take into account any potential endogeneity of such explanatory variables is performed. Results of the multicollinearity test may be measured by the value of the variance inflation factor (VIF). According to Kutner et al. (2005), a VIF value higher than 10 indicates multicollinearity. Table 1 indicates no multicollinearity within the independent variables. A second check for robustness is conducted. Durbin Watson values less than 2.50, showing no signs of multicollinearity for all our models.

The use of OLS as an estimation methodology may suffer from heterogeneity bias in the gravity model context (Cheng, Wall 2005). Trade between any pair of countries is likely to be influenced by certain unobserved individual effects. If these effects are correlated with the explanatory variables, which an examination of the OLS residuals supports, this will lead to pooled OLS estimates being biased. Therefore, two more models of estimation are employed in this study: the fixed effects model and the random effects model, as presented in the following sections.

\subsection{Fixed and random effects models}

The fixed effect model is the most appropriate way to exploit the panel nature of the data set without making heroic assumptions (Glick, Rose 2002). Above and beyond econometric robustness, the fixed effect estimator has one enormous advantage. In the FEM, the intercept terms are allowed to vary over the individual unit, but are held constant over time.

Estimation results are in Table 2 where the results of the fixed effects estimates are presented in models (d), (e) and (f). For comparison purposes, the random effects model is also estimated in models (g), (h) and (i), using a generalized least-squares estimator assuming Gaussian disturbances that are uncorrelated with the random (country-pair specific) effects. 
Table 2. Fixed and random effects models

\begin{tabular}{lccccccc}
\hline \multicolumn{1}{c}{ Time Frames } & $2000-2006$ & $2007-2012$ & $2000-2012$ & $2000-2006$ & $2007-2012$ & $2000-2012$ \\
\hline \multicolumn{1}{c}{ Models } & $(\mathrm{d})$ & $(\mathrm{e})$ & $(\mathrm{f})$ & $(\mathrm{g})$ & $(\mathrm{h})$ & $(\mathrm{i})$ \\
\hline Dependent variables & \multicolumn{5}{c}{ Fixed Effects Model } & \multicolumn{3}{c}{ Random Effects Model } \\
\hline (c) $\log (G)$ & 0.336 & 0.312 & 0.336 & 0.341 & 0.316 & 0.341 \\
& $(0.000)^{* * * *}$ & $(0.000)^{* * * *}$ & $(0.000)^{* * * *}$ & $(0.000)^{* * * *}$ & $(0.000)^{* * * *}$ & $(0.000)^{* * * *}$ \\
\hline$(\mathrm{d}) \log (P)$ & 0.533 & 0.548 & 0.559 & 0.526 & 0.538 & 0.551 \\
& $(0.000)^{* * * *}$ & $(0.000)^{* * * *}$ & $(0.000)^{* * * *}$ & $(0.000)^{* * * *}$ & $(0.000)^{* * * *}$ & $(0.000)^{* * * *}$ \\
\hline (e) CL & - & - & - & -0.259 & -0.249 & -0.253 \\
& & & & $(0.000)^{* * * *}$ & $(0.000)^{* * * *}$ & $(0.000)^{* * * *}$ \\
\hline Constant & -2.467 & -2.417 & -2.840 & -2.260 & -2.162 & -2.609 \\
& $(0.000)^{* * * *}$ & $(0.000)^{* * * *}$ & $(0.000)^{* * * *}$ & $(0.000)^{* * * *}$ & $(0.000)^{* * * *}$ & $(0.000)^{* * * *}$ \\
\hline $\mathrm{R}^{2}$ & 0.632 & 0.726 & 0.707 & 0.640 & 0.734 & 0.715 \\
\hline No. of countries & 189 & 189 & 189 & 189 & 189 & 189 \\
\hline No. of observations & 1327 & 1059 & 2333 & 1327 & 1059 & 2333 \\
\hline Durbin Watson & 2.064 & 2.131 & 2.075 & 2.070 & 2.130 & 2.077 \\
\hline F-test & 1138.475 & 1395.698 & 2817.873 & 784.464 & 968.657 & 1949.084 \\
\hline VIF values & 1.066 & 1.036 & 1.046 & 1.070 & 1.038 & 1.049 \\
& 1.066 & 1.036 & 1.046 & 1.078 & 1.061 & 1.065 \\
\hline & & & & 1.021 & 1.030 & 1.026 \\
\hline
\end{tabular}

Notes: Annual data for 189 countries; p-values are in parentheses; ${ }^{*}$ significant at $10 \%$, ${ }^{*}$ significant at $5 \%,{ }^{* * *}$ significant at $1 \%,{ }^{* * *}$ significant at $0.01 \%$; (c) $G=G D P$ per capita; (d) $P=$ population of a country; (e) $C L=$ common language; VIF values are reported for each of the explanatory variables (c), (d) and (e).

The fixed effects model works well in a number of different dimensions. The model fits the data well, explaining $63.2 \%$ of the variation in trade flows for $2000-2006,72.6 \%$ of the variation in trade flows for 2000-2006, 70.7\% of the variation in trade flows for 2000-2012. Results show highly significant results at $0.01 \%$ for GDP and population implying that larger and richer countries trade more for all three time frames.

A check to take into account any potential endogeneity of such explanatory variables is performed. Results of the multicollinearity test may be measured by the value of the variance inflation factor (VIF) are all a little more than 1.0, showing very low signs of multicollinearity. A second check for robustness using the Durbin Watson method shows that all values are less than 2.50 again, showing no signs of multicollinearity for models (d), (e) and (f).The fixed effects estimates, are thus, not only economically and statistically significant, but seems robust.

The random effects model also works well in a number of different dimensions as presented in models (g), (h) and (i). The model fits the data well, explaining even better than the fixed effects model, holding values of $64 \%$ of the variation in trade flows for 2000 $2006,73.4 \%$ of the variation in trade flows for $2000-2006,71.5 \%$ of the variation in trade flows for 2000-2012. Results show highly significant results at $0.01 \%$ for GDP, population and common language. This implies that larger and richer countries trade more for all three time frames, and that countries which share a common language also trade more. 
A check to take into account any potential endogeneity of such explanatory variables is performed. Results of the multicollinearity test may be measured by the value of the variance inflation factor (VIF) are all a little more than 1.0, showing very low signs of multicollinearity. A second check for robustness using the Durbin Watson method shows that all values are less than 2.50 again, showing no signs of multicollinearity for models (g), (h) and (i).The random effects estimates, are thus, not only economically and statistically significant, but seem robust.

To summarize: a number of different panel estimators all deliver the conclusion that Internet has a strong positive effect on trade in education. The fixed effects model shows a good fit, and that trade in education does not have any additional determinants other than those reflected in the regression equation that may facilitate or hinder trade in education. The random effects model applies, showing that country-specific effects does not matter that may facilitate or hinder trade in education.

\section{Conclusions}

Intuition tells us that the Internet may have impact trade in education in many ways. Institutions are able to reach individuals in ways never ever possible before. Individuals are able to access information to institutions in any corner of the world in ways never ever possible before. Trade in education has also become a major source of economic wealth for many nations, especially for developed countries. Not only governments from developed as well as developing countries are increasingly relying on it as a major source of trade and economic boost, institutions are also relying on it as a major source of income. However, little do we know how the Internet impacts trade in education. Thus, this study responds to the call for studies in this area. It looks at the role of Internet on a worldwide scale and examines across three time frames.

Results suggest that Internet development over time facilitates increased trade in education. Specifically, between 2000 and 2006, the impact of the Internet on trade in education is about $16.4 \%$ for a $0.01 \%$ increase in the Internet variable. Between 2007 and 2012 , the impact of the Internet is about $18 \%$ for a $0.01 \%$ increase in the Internet variable. On the aggregate, between 2000 and 2012, the impact of the Internet is about $21 \%$ for a $0.01 \%$ increase in the Internet variable. Our results show much greater significances of the impact of the Internet than existing studies by Choi (2010) and Freund and Weinhold (2002). The study by Choi (2010) finds that for every $1 \%$ increase in Internet users per hundred people, service exports increase by $4.3 \%$. The study by Freund and Weinhold (2002) find that for every $10 \%$ increase in Internet users per hundred people, exports grow by $0.2 \%$. The results of this study not only show similar trends, but one of much greater significance on trade in comparison.

This study finds mixed results for fixed (wired) broadband over the three time frames. Results are in line with global trends presented in the introduction section, where the implication is that there may be cross-country variations in access of fixed (wired) broadband due to different patterns of economic growth as well as different stages of economic development making it harder to generalize its impact on trade. On the other hand, results 
for the Internet are highly significant for all three time frames. For every $0.01 \%$ increase in Internet access, trade in education increases by $16.4 \%$ between 2000 and 2006 by $18 \%$ between 2007 and 2012, and by $21 \%$ between 2000 and 2012.Having a common language is also a highly significant factor for trade in education for all three time frames at $0.01 \%$.

The augmented gravity model works well and fits the data well, explaining $65.8 \%$ of the variation in trade flows for 2000-2006; 74.9\% of the variation in trade flows for 2000-2006; and $71.9 \%$ of the variation in trade flows for 2000-2012. Larger countries and countries sharing a common language are highly significant factors for trade in education for all three time frames at $0.01 \%$. However, the economic health of a country does not necessarily imply greater trade as the Internet accessibility worldwide increases over the second time frame between 2006 and 2012. When ordering the impact of each variable's significance on trade in education, larger countries come in first, followed by common language, and finally the Internet.

While this study adds to existing literature in many ways, it consists of several limitations. First, while this study provides a general and macroscopic view of the impact of the Internet on trade in education, it neglected its impact on specific countries. Future studies could investigate on the impact of the Internet on specific countries and compare it our generalized results. A second limitation of this study is that although our data includes a large sample of countries in the world of up to 189 countries and may be thus, easier to generalize our conclusions, it does not differentiate between stages of countries' development. Future studies could categorize countries into different stages of economic development such as developed, transitional, and developing economies.

In conclusion, this paper finds that an increase in a country's Internet/ICT access will facilitate trade in education. We can expect future development in the Internet and other advanced ICTs to contribute to the expansion of trade in education in all other modes trade in education including e-learning, foreign direct investment in terms of commercial presence overseas, thus, contributing to a country's trade in education. From a global perspective, if a country improves access to the Internet, trade in education exports will increase.

\section{References}

Aitken, N. D. 1973. The effect of EEC and EFTA on European trade: a temporal cross-section analysis, American Economic Review 63: 881-892.

AIBS. 2014. Australia's international business survey: 2014 report, Export Council of Australia/University of Sydney 2014 [online], [cited 14 January 2015]. ISSN 2203-5664. Available from Internet: http:// sydney.edu.au/business/data/assets/pdffile/0015/201651/AIBS_2014_Report.pdf

Baliamoune, M. N. 2002. The new economy and developing countries, Working Paper. WIDER discussion papers, World Institute for Development Economics (UNU-WIDER) 2002/77.

Baldwin, R. 1994. Towards an integrated Europe. CEPR, London.

Bankolea, F. O.; Osei, B.; Brown, K. M. 2015. The impact of information and communications technology infrastructure and complementary factors on Intra-African trade, Information Technology for Development 21(1): 12-18. http://dx.doi.org/10.1080/02681102.2013.832128

Bergstrand, J. H. 1985. The gravity equation in international trade: some microeconomic foundations and empirical, The Review of Economics and Statistics 67(3): 474-481. http://dx.doi.org/10.2307/1925976 
BIS. 2011. Estimating the value to the UK of education exports [online]. BIS Research Paper Number 46, June 2011. Department of Business Innovation and Skills [cited 14 January 2015]. Available from Internet: http://www.bis.gov.uk/assets/biscore/higher-education/docs/e/11-980-estimating-valueof-education-exports.pdf

Bohm, A.; Follari, M.; Hewett, A.; Jones, S.; Kemp, N.; Meares, D.; Pearce, D.; Cauter, K. V. 2004. Forecasting international student mobility: a UK perspective [online], British Council Vision 2020 report [cited 14 January 2015]. Available from Internet: http://www.britishcouncil.org/sites/britishcouncil. uk2/files/vision-2020.pdf

Bourke, A. 2000. A model of the determinants of international trade in higher education, The Service Industries Journal 20(1): 110-138. http://dx.doi.org/10.1080/02642060000000007

Caselli, F.; Coleman, W. J. II. 2001. Cross-country technology diffusion: the case of computers, American Economic Review 91: 328-335. http://dx.doi.org/10.1257/aer.91.2.328

Cheng, I.-H.; Wall, H. J. 2005. Controlling for heterogeneity in gravity models of trade and integration, Federal Reserve Bank of St. Louis Review 87(1): 49-63.

Choi, C.; Yi, M. H. 2009. The effect of the Internet on economic growth: evidence from cross-country panel data, Economics Letters 10(5): 39-41. http://dx.doi.org/10.1016/j.econlet.2009.03.028

Choi, C. 2010. The effect of the Internet on service trade, Economics Letters 109(2): 102-104. http://dx.doi.org/10.1016/j.econlet.2010.08.005

Clarke, G. R.; Wallsten, S. J. 2006. Has the Internet increased trade? Developed and developing country evidence, Economic Inquiry 44(3): 465-484. http://dx.doi.org/10.1093/ei/cbj026

Damijan, J. P.; Knell, M.; Majcen, B. 2003. The role of FDI, R\&D accumulation and trade in transferring technology to transition countries: evidence from firm panel data for eight transition countries, Economic Systems 27(2): 189-204. http://dx.doi.org/10.1016/S0939-3625(03)00039-6

Department of Foreign Affairs and Trade (DFAT). 2013. Australia's trade in goods and services 2012-13 [online]. Department of Foreign Affairs and Trade [cited 14 January 2015]. Available from Internet: http://dfat.gov.au/about-us/publications/trade-investment/australias-trade-in-goods-and-services/ Pages/australias-trade-in-goods-and-services-2012-13.aspx

Fink, C.; Mattoo, A.; Neagu, I. C. 2005. Assessing the impact of communication costs on international trade, Journal of International Economics 67(2): 428-445. http://dx.doi.org/10.1016/j.jinteco.2004.09.006

Freund, C.; Weinhold, D. 2002. The Internet and international trade in services, The American Economic Review 92(2): 236-240. http://dx.doi.org/10.1257/000282802320189320

Freund, C.; Weinhold, D. 2004. The effect of the Internet on international trade, Journal of International Economics 62: 171-189. http://dx.doi.org/10.1016/S0022-1996(03)00059-X

Glick, R.; Rose, A. K. 2002. Does a currency union affect trade? The time-series evidence, European Economic Review 46(6): 1125-1151. http://dx.doi.org/10.1016/S0014-2921(01)00202-1

Grossman, G. M.; Helpman, E. 1995. Technology and trade, in G. M. Grossman, K. Rogoff (Eds.). Handbook of international economics. Handbooks in economics, vol. 3. Amsterdam, New York, Oxford: Elsevier, 1279-1337. http://dx.doi.org/10.1016/S1573-4404(05)80005-X

Internet World Stats. 2000-2012. Internet usage and world population statistics [online], [cited 14 January 2015]. Available from Internet: http://www.internetworldstats.com/list2.htm

Internet World Stats. 2014. Internet usage statistics, the Internet big picture, world Internet users and 2014 population statistics [online], [cited 14 January 2015]. Available from Internet: http://www. internetworldstats.com/stats.htm

ITU. 2000-2014. Information and communicative technology data, 2000-2014 [online]. International Telecommunication Union [cited 14 January 2015]. Available from Internet: http://www.itu.int/en/ ITU-D/Statistics/Pages/stat/default.aspx 
Kenny, C. 2003. The Internet and economic growth in less-developed countries: a case of managing expectations?, Oxford Development Studies 31(1): 99-113. http://dx.doi.org/10.1080/1360081032000047212

Kunin, R.; Associates, Incorporated. 2012. Economic impact of international education in Canada - an update: final report [online]. Department of Foreign Affairs and International Trade, Canada [cited 20 January 2015]. Available from Internet: http://www.international.gc.ca/education/assets/pdfs/ economic_impact_en.pdf

Kutner, M. H.; Nachtsheim, C. J.; Neter, J.; Li, W. 2005. Applied linear statistical models. 5th ed. Boston: McGraw-Hill/Irwin.

Lanvin, B. 1989. Information, services and development: some conceptual and analytical issues, in J. Bressand, P. Nicolaides (Eds.). Strategic trends in services: an enquiry into the global economy. London: Harper and Row.

Larsen, K.; Martin, J. P.; Morris, R. 2002. Trade in educational services: trends and emerging issues, World Economy 25(6): 849-868. http://dx.doi.org/10.1111/1467-9701.00466

Limão, N.; Venables, A. J. 2001. Infrastructure, geographical disadvantage, and transport costs, World Bank Economic Review 15(3): 451-479. http://dx.doi.org/10.1093/wber/15.3.451

Lipsey, R. E. 2009. Measuring international trade in services, in M. Reinsdorf, M. J. Slaughter (Eds.). International trade in services and intangibles in the era of globalization [online], [cited 20 January 2015]. University of Chicago Press, 27-70. ISBN 978-0-226-70959-8, 0-226-70959-0. Available from Internet: http://www.nber.org/books/rein09-1

Mátyás, L. 1997. Proper econometric specification of the gravity model, The World Economy 20(3): 363-368. http://dx.doi.org/10.1111/1467-9701.00074

Mátyás, L. 1998. The gravity model: some econometric considerations, The World Economy 21(3): 397-401. http://dx.doi.org/10.1111/1467-9701.00136

OECD. 2000-2012. OECD data portal 2000-2012 [online], [cited 14 January 2015]. The Organisation for Economic Co-operation and Development. Available from Internet: http://www.oecd.org/ statistics/

OECD. 2007. Moving up the value chain: staying competitive in the global economy [online]. The Organisation for Economic Co-operation and Development [cited 14 January 2015]. Available from Internet: http://www.oecd.org/sti/ind/38558080.pdf

Poyhonen, P. 1963. A tentative model of the volume of trade between countries, Journal of Economics and Finance Archive 90(1): 35-35.

Saggi, K. 2002. Trade, foreign direct investment, and international technology transfer: a survey, World Bank Research Observer 17(2): 191-235. http://dx.doi.org/10.1093/wbro/17.2.191

Tang, L. H. 2006. Communication costs and trade of differentiated goods, Review of International Economics 14(1): 54-68. http://dx.doi.org/10.1111/j.1467-9396.2006.00560.x

Tay, C. 2014a. An econometric model on bilateral trade in education using an augmented gravity model, Journal of Industrial Engineering and Management 7(2): 401-412. http://dx.doi.org/10.3926/jiem.1009

Tay, C. 2014b. International marketing of education services: trends, obstacles and issues, in Proceedings of 2013 International Conference on Logistics, Informatics and Services Sciences. Berlin: Springer Berlin Heidelberg, 584-587. ISBN 978-3-642-40659-1.

http://dx.doi.org/10.1007/978-3-642-40660-7_6

Tinbergen, J. 1962. Shaping the world economy; Suggestions for an international economic policy [online]. Books (Jan Tinbergen). New York: Twentieth Century Fund [cited 18 January 2015]. Available from Internet: http://hdl.handle.net/1765/16826

The World Bank. 2000-2012. The World Bank data 2000-2012 [online]. The World Bank [cited 14 January 2015]. Available from Internet: http://data.worldbank.org 
UNESCO. 2000-2012. UIS Data Centre 2000-2012 [online]. UNESCO Institute of Statistics. United Nations Educational, Scientific and Cultural Organization [cited 14 January 2015]. Available from Internet: http://www.uis.unesco.org/datacentre/pages/default.aspx?SPSLanguage=EN

Vemuri, V. K.; Siddiqi, S. 2009. Impact of commercialization of the Internet on international trade: a panel study using the extended gravity model, The International Trade Journal 23(4): 458-484. http://dx.doi.org/10.1080/08853900903223792

Wang, E. H. 1999. ICT and economic development in Taiwan: analysis of the evidence, Telecommunications Policy 23(3-4): 235-243. http://dx.doi.org/10.1016/S0308-5961(99)00005-1

WTO. 2010. Measuring trade in services: a training module for the World Bank [online]. November 2010. World Trade Organization [cited 14 January 2015]. Available from Internet: http://www.wto.org/ english/res_e/statis_e/services_training_module_e.pdf

\section{APPENDIX A}

List of countries in study (189)

\begin{tabular}{|c|c|c|c|c|c|}
\hline Afghanistan & Colombia & Haiti & Mali & Rwanda & Turkmenistan \\
\hline Albania & Comoros & Honduras & Malta & $\begin{array}{l}\text { St. Kitts and } \\
\text { Nevis }\end{array}$ & Tuvalu \\
\hline Algeria & $\begin{array}{l}\text { Congo, } \\
\text { Democratic } \\
\text { Republic of the }\end{array}$ & Hungary & $\begin{array}{l}\text { Marshall } \\
\text { Islands }\end{array}$ & St. Lucia & Uganda \\
\hline Andorra & $\begin{array}{l}\text { Congo, } \\
\text { Republic of }\end{array}$ & Iceland & Mauritania & $\begin{array}{l}\text { St. Vincent and } \\
\text { the Grenadines }\end{array}$ & Ukraine \\
\hline Angola & Costa Rica & India & Mauritius & Samoa & $\begin{array}{l}\text { United Arab } \\
\text { Emirates }\end{array}$ \\
\hline $\begin{array}{l}\text { Antigua and } \\
\text { Barbuda }\end{array}$ & Côte d'Ivoire & Indonesia & Mexico & San Marino & $\begin{array}{l}\text { United } \\
\text { Kingdom }\end{array}$ \\
\hline Argentina & Croatia & Iran & Micronesia & $\begin{array}{l}\text { São Tomé and } \\
\text { Príncipe }\end{array}$ & Uruguay \\
\hline Armenia & Cuba & Iraq & Moldova & Saudi Arabia & Uzbekistan \\
\hline Australia & Cyprus & Ireland & Monaco & Senegal & Vanuatu \\
\hline Austria & $\begin{array}{l}\text { Czech } \\
\text { Republic }\end{array}$ & Israel & Mongolia & Serbia & Venezuela \\
\hline Azerbaijan & Denmark & Italy & Montenegro & Seychelles & Vietnam \\
\hline Bahamas & Djibouti & Jamaica & Morocco & Sierra Leone & Yemen \\
\hline Bahrain & Dominica & Japan & Mozambique & Singapore & Zambia \\
\hline Bangladesh & $\begin{array}{l}\text { Dominican } \\
\text { Republic }\end{array}$ & Jordan & Myanmar & Slovakia & Zimbabwe \\
\hline Barbados & Ecuador & Kazakhstan & Namibia & Slovenia & Uruguay \\
\hline Belarus & Egypt & Kenya & Nepal & $\begin{array}{l}\text { Solomon } \\
\text { Islands }\end{array}$ & \\
\hline Belgium & El Salvador & Kiribati & Netherlands & Somalia & \\
\hline Belize & $\begin{array}{l}\text { Equatorial } \\
\text { Guinea }\end{array}$ & Korea, North & New Zealand & South Africa & \\
\hline
\end{tabular}


End of Appendix A

\begin{tabular}{|c|c|c|c|c|}
\hline Benin & Eritrea & Korea, South & Nicaragua & South Sudan \\
\hline Bhutan & Estonia & Kuwait & Niger & Spain \\
\hline Bolivia & Ethiopia & Kyrgyzstan & Nigeria & Sri Lanka \\
\hline $\begin{array}{l}\text { Bosnia and } \\
\text { Herzegovina }\end{array}$ & Fiji & Laos & Norway & Sudan \\
\hline Botswana & Finland & Latvia & Oman & Suriname \\
\hline Brazil & France & Lebanon & Pakistan & Swaziland \\
\hline Brunei & Gabon & Lesotho & Palau & Sweden \\
\hline Bulgaria & Gambia & Liberia & Panama & Switzerland \\
\hline Burkina Faso & Georgia & Libya & $\begin{array}{l}\text { Papua New } \\
\text { Guinea }\end{array}$ & Syria \\
\hline Burundi & Germany & Liechtenstein & Paraguay & Tajikistan \\
\hline Cambodia & Ghana & Lithuania & Peru & Tanzania \\
\hline Cameroon & Greece & Luxembourg & Philippines & Thailand \\
\hline Canada & Grenada & Macedonia & Poland & Togo \\
\hline $\begin{array}{l}\text { Central } \\
\text { African } \\
\text { Republic }\end{array}$ & Guatemala & Madagascar & Portugal & Tonga \\
\hline Chad & Guinea & Malawi & Qatar & $\begin{array}{l}\text { Trinidad and } \\
\text { Tobago }\end{array}$ \\
\hline Chile & Guinea-Bissau & Malaysia & Romania & Tunisia \\
\hline China & Guyana & Maldives & Russia & Turkey \\
\hline
\end{tabular}

Christina TAY. Assistant Professor at the Department of International Business, and Deputy Dean and Chief of Accreditation at the School of Continuing Education of Chinese Culture University. Author and co-author of more than 19 scientific articles and 5 books. Research interests: Trade in Education, Information and Communication Technologies, International business, Service science, International higher education, Service Industry, Total Quality Management, Management. 